\title{
KEKERASAN TERHADAP PEREMPUAN DALAM BAHASA DAN MEDIA
}

Drs. H. Mudjia Rahardjo, M.Si. Puket IV STAIN Mialang

Drs. H. Mudjia Rahardjo, M.Si. Lahir di Blitar, 1 Januari 1959. Kini sedang meneruskan di Program Doktor UNAIR Surabàya dengan mengambil spesifikasi Sosio Linguistik. Di STAIN Malang ia menjabat sebagai PUKET IV, Anggota Dewan Redaksi elHarakah dan sebagai dosen tetap STAIN Malang dengan keahlian mata kuliah Bahasa Inggris. Aktif mengisi forum-forum dialog, seminar di berbagai perguruan tinggi dan menulis, baik dalam bentuk diktat, artikel yang dipublikasikan di berbagai mass media atau tulisan-tulisan ilmiah. Melakukan beberapa penelitian. baik kelompok atau individual.

\section{A. Pengantar}

Salah satu wacana publik yang paling mencolok selama satu dekade terakhir adalah ketidakadilan dan ketidaksetaraan berdasarkan perbedaan jenis kelamin sosial (gender). Meminjam Jody Williams, pemenang Hadiah Nobel Perdamaian 1997, ketika berbicara dalam seminar "Gender and Media" pada Fukuoka International Women's Forum 2000 di Fukuoka Jepang belum lama ini, gender telah menjadi semacam "isu yang seksi" di dunia (Kompas, 1/11/00). Wajar jika gender lantas menarik minat para akademisi dari berbagai bidang dan disiplin ilmu untuk mengkaji lebih jauh. Diskusi, perdebatan, seminar, bahkan sekadar pernyataan tentang gender dari berbagai perspektif lantas mengisi khasanah akademik.

Bahasa dan media dituding sebagai alat yang efektif untuk mengekalkan dominasi laki-laki atas perempuan melalui kata maupun gambar. Tulisan ini akan mengulas bagaimana bahasa menggunakan kata yang dengan sengaja 'meminggirkan' kaum perempuan. Sedangkan media terus menerus memuat gambar dan peristiwa yang juga memojokkan dan merendahkan martabat kaum perempuan. Karena banyaknya perspektif tentang kekerasan, tulisan ini hanya akan memahami kekerasan menurut perspektif Galtung. Sebab, sebagaimana diketahui Johan Galtung merupakan sosiolog yang mencurahkan perhatiannya pada kekerasan sebagai fenomena sosial dua dasa warsa terakhir.

Dunia akademik lantas menempatkan Galtung pada deretan ilmuwan-ilmuwan sosial kenamaan lainnya. Kontribusi buah pena dan pemikirannya tentang kekerasan yang sangat tajam dan komprehensif memperkaya khasanah akademik, khususnya dalam ilmu sosial.

Analisis kekerasan terkait dengan bahasa dirasa sangat urgen mengingat menyusul kelahiran post-modernism dan post-structuralism dalam kancah filsafat dan epistemologi modern, bahasa tidak saja dimengerti sebagai alat komunikasi sebagaimana 
Melekatnya budaya patriarkhi pada masyarakat kita dan Asia pada umumnya, seakan menguatkan mitos bahwa perempuan sebagai makhluk yang secara fisik lemah, rapuh, tidak tegas karenanya harus dilindungi, disayangi dan disanjung,dan secara kodrati kurang pandai karenanya hanya layak mengerjakan pekerjaan yang bersifat domestik dan tidak banyak berhubungan dengan orang luar. Pekerjaan yang berhubungan dengan 'orang luar' menjadi tanggung jawab laki-laki, karena dikhawatirkan perempuan tidak mampu (?) menyelesaikannya. perspektif konvensional memandang bahasa. Tetapi bahasa, menurut Hikam (1996: 77), di dalam dirinya tampil sebagai representasi dari dan ruang bagi penggelaran berbagai konflik dan kepentingan, kekuatan, kekuasaan, serta hegemoni.

B. Budaya Patriarkhi, Ketidakadilan dan Ketidaksetaraan Gender

Diskursus tentang gender hampir tidak lepas dari persoalan ketidakadilan dan ketidaksetaraan berdasarkan jenis kelamin. Hampir setiap hari kita menyaksikan media massa memuat pernyataan berbagai pihak, terinasuk pemerintah, tentang keadilan dan kesetaraan gender. Tetapi anehnya disadari atau tidak, ideologi yang merendahkan perempuan terus muncul di berbagai media baik melalui pemilihan kata, gambar, maupun keseluruhan visi berita. Secara terus menerus media menggunakan perempuan sebagai komoditas obyek seks dan kekerasan

Melekatnya budaya patriarkhi pada masyarakat kita dan Asia pada umumnya, seakan menguatkan mitos bahwa perempuan sebagai makhluk yang secara fisik lemah, rapuh, tidak tegas karenanya harus dilindungi, disayangi dan disanjung,dan secara kodrati kurang pandai karenanya hanya layak mengerjakan pekerjaan yang bersifat domestik dan tidak banyak berhubungan dengan orang luar. Pekerjaan yang berhubungan dengan 'orang luar' menjadi tanggung jawab lakilaki, karena dikhawatirkan perempuan tidak mampu (?) menyelesaikannya. Sedangkan pria dilukiskan sebagai makhluk kesatria, selalu kuat, gagah, pemberani, dan sebagainya. Bahkan kaitannya dengan ideologi, Tuhan pun dinyatakan dalam figur pria. Orang Katolik dalam berdo'a menyatakan Bapak, Putera, dan Ruh Kudus. Dalam bahasa Inggris, kata ganti Tuhan ialah "He" (male pronoun).

Sepintas mitos terhadap perempuan seperti itu sepintas menempatkan perempuan pada posisi aman karena terlindungi. Tetapi sebenarnya keseluruhan atribut yang melekat pada perempuan tersebut justru melemahkan eksistensi perempuan sebagai manusia. Padahal menurut Kant dan Hegel (Rahardjo, 2000) manusia, laki-laki dan perempuan, adalah produsen ideide besar yang sangat produktif. Sejarah panjang dunia diisi oleh ide-ide besar manusia, yang di dalamnya termasuk perempaun. 


\section{Kekerasan dalam Pandangan Galtung}

Menurut Johan Galtung, sosiolog yang mengkususkan diri pada fenomena kekerasan, notion yang melemahkan derajat perempuan yang membatasi gerak dan ruang kehidupannya termasuk non-violence violence (kekerasan tanpa kekerasan).Galtung (dalam Windu, 2000) menyebutkan bahwa pada diri manusia terbentang dua dunia besar yang berbeda, tetapi tidak bisa dipisahkan: dunia potensi dan dunia aktual. Yang pertama terkait dengan realitas yang tidak tampak dan belum terwujud, seperti cita-cita, mimpi, afeksi, kehendak, gagasan, memori, dan segala jenis nilai yang dipegang dan diperjuangkan. Sedangkan yang kedua terkait dengan realitas yang sudah terwujud dan tampak sebagaimana dapat kita lihat, raba, dengar, saksikan, dan rasakan.

Lebih lanjut, masih menurut Galtung, kekerasan terjadi jika manusia dipengaruhi sedemikian rupa oleh pihak lain sehingga realisasi jasmani dan mental aktualnya berada di bawah realisasi potensialnya. Atas dasar ini, kekerasan bukan hanya soal memukul, melukai, menganiaya, sampai membunuh, tetapi lebih luas dari itu. Negara menelantarkan rakyat sehingga banyak yang menderita kelaparan, memasung hak berdemokrasi, melakukan pelecehan HAM, penyalahgunaan kekuasaan dan wewenang oleh pejabat negara, mempersempit ruang gerak dan berkarya seseorang dengan alasan apapun, termasuk jenis kelamin, menyakiti dan melukai hati orang melalui ungkapanungkapan bahasa yang keras dan vulgar, menayangkan gambar bagian tubuh perempuan sebagai komoditas publikasi dan merendahkan martabat manusia dengan sendirinya adalah praktik kekerasan.

Kekerasan terhadap perempuan dalam bahasa juga tampak jelas. Misalnya, mengapa seorang pelacur disebut WTS (Wanita Tuna Susila). Padahal, pelacuran suatu kegiatan yang melibatkan paling tidak dua pihak: yang melacurkan diri dan orang yang memanfaatkan jasa tersebut, bahkan masih ada lagi germo, yang jiistru, paling beruntung (Noerhadi, 1989). Tapi siapa yang tuna sussila? Bukan sang getmo, bukan yang memantadtkan jasa pelacuran, tetapi si wanita. Apakah bukan pihak pria yang disebut tuna susila, sehingga ada istilah PTS (Pria Tuna Susila).

Di tengah praktik kekerasan yang melanda bangsa yang akhir-akhir ini meraja lela, praktik kekerasan terhadap

Menurut Johan
Galtung, sosiolog
yang
mengkususkan diri
pada fenomena
kekerasan, notion
yang melemahkan
derajat perempuan
yang membatasi
gerak dan ruang
kehidupannya
termasuk non-
violence violence
(kekerasan tanpa
kekerasan)


kekuatan yang dimiliki sebagai penggalang dan pembentuk opini publik, media memang dengan gampang menayangkan peristiwa-peristiwa yang mereka sukai yang barangkali tidak lagi mengedepankan pada aspek obyektivitas, tetapi lebih pada komoditas dan konsumsi publik perempuan, baik sebagai pelaku maupun korban, juga juduljudul berita media massa yang sensasional, melemahkan dan berkonotasi negatif terhadap perempuan seakan mewarnai konflik sosial di negeri ini. Misalnya, peristiwa pemerkosaan yang disertai pembunuhan pasti akan menjadi headline besar di media massa. Mengapa peristiwa itu terjadi, bagaimana latar belakang pelaku, bagaimana pula penderitaan korban sesudahnya jarang atau bahkan tidak dipublikasikan.

Dengan kekuatan yang dimiliki sebagai penggalang dan pembentuk opini publik, media memang dengan gampang menayangkan peristiwa-peristiwa yang mereka sukai yang barangkali tidak lagi mengedepankan pada aspek obyektivitas, tetapi lebih pada komoditas dan konsumsi publik. Inilah yang menurut Watts (1999) disebut sebagai media bias. Media bias banyak terjadi ketika sedang berlangsung kampanye pemilihan presiden Amerika Serikat selama musim kampanye 1988, 1992, dan 1996.

Menurut penelitian Watts, betapa media memiliki kekuatan dahsyat membangun opini publik bagi calon presiden yang mereka sukai. Opini masyarakat terhadap seorang calon presiden bisa berubah drastis begitu media memuat kelemahan dan kekurangannyà. Tetapi di saat yang bersamaan seorang calon bisa terangkat popularitasnya begitu media memuat tentang kehebatan dan kelebihannya.

\section{Kekerasan terhadap Perempuan dalam Bahasa}

Kaum post-modernis dan post-strukturalis memandang bahasa bukan sekadar alat komunikasi, tetapi juga merupakan tempat terjadinya pergolakan berbagai kepentingan dan kekuasaan. Karenanya, memilih kata dalam bahasa artinya memilih maksud tertentu yang hendak dicapai. Menurut George Orwell, bahasa bukan sekadar alat komunikasi. Tetapi ia merupakan suatu kegiatan sosial yang terstruktur dan terikat pada keadaan sosial tertentu. Artinya, menurut Foucault (1972) kendati manusia menguasai bahasa, dia tidak lantas bebas mengucapkan kata tertentu sesuai yang dia mau. Dia mesti memikirkan bagaimana dampaknya bagai orang dan pihak lain atas ucapan dan pemilihan katanya.

Meminjam Bosmajian dalam The Language of Opression 
(1983) bahasa (dalam huruf dan gambar) ikut mengkonstruksikan perempuan dalam posisinya sebagai the second class citizen (masyarakat kelas dua), karena perempuan merupakan the second sex, menurut Simone de Beauvoir (Kompas 1/11/00).

Lebih lanjut, Christ Weedon, seorang post-strukturalis, mengatakan bahasa juga merupakan wilayah di mana rasa tentang diri, subyektivitas, termasuk definisi tentang perempuan dan laki-laki serta apa yang baik dan buruk dari masing-masing jenis ini dibentuk. Hal ini terjadi karena bahasa adalah kekuatan, pertentangan, dan pergulatan. Menurut Terry Eagleton dalam What is Ideology ?(1991) bahasa juga adalah situs bagi dampakdampak ideologis yang memiliki kekuatan dahsyat untuk membentuk perilaku pembacanya. Dengan demikian, pembicaraan mengenai ideologi tidak mungkin dilepaskan dari pembicaraan mengenai bahasa.

Bahasa harus dipahami sebagai sesuatu yang memiliki ketertujuan (teleologi) di dalam dirinya. Meminjam Gadamer (1977:27) bahwa kata atau ungkapan secara aksidental tidak pernah memiliki kebakuan. Dia mempunyai tujuan (telos) tersendiri atau penuh dengan maksud. Karenanya, setiap kata tidak pernah tidak bermakna (Sumaryono, 1999: 27). Menurut Derida, tokoh post-modernis, dalam Sumaryono (1999: 130) bahasa adalah intensionalitas. Bahasa bukan deretan kata-kata yang sudah jadi yang kemudian dipilih oleh pemakainya secara bebas. Karena itu pula, ketika pelacur dikatakan sebagai WTS (Wanita Tuna Susila), maka di balik pemilihan kata tersebut ada makna yang secara gamblang melecehkan martabat perempuan. Inilah dahsyatnya sebuah kata. Perempuan yang telah menjadi pemuas nafsu birahi laki-laki masih dilecehkan pula martabatnya sebagai Tuna Susila.

Hal yang sama juga terjadi pada kata Polwan. Mengapa kalau polisi selalu berasosiasi dengan laki-laki. Sedangkan kalau ada polisi perempuan, dia disebut Polwan. Tetapi kata-kata seperti sekretaris dan perawat, pembantu, juru masak, profesi yang terkait dengan urusan domestik, langsung mengacu pada perempuan. Masih banyak lagi contoh yang lain. Inilah bukti betapa dalam bahasa perempuan juga terpinggirkan.

E. Kekerasan terhadap Perempuan dalam Media
Sedangkan kalau ada polisi perempuan, dia disebut Polwan. Tetapi kata-kata seperti sekretaris dan perawat, pembantu, juru masak, profesi yang terkait dengan urusan domestik, langsung mengacu pada perempuan. Masih banyak lagi contoh yang lain. Inilah bukti betapa dalam bahasa perempuan juga terpinggirkan. 
Mengapa bagianbagian itu yang ditonjolkan oleh juru foto? Apakah bagian bagian tubuh perempuan yang tertutup itu lebih

menggairahkan? Apakah itu merupakan nafsunafsu tersembunyi dari para pengambil gambar? Atau keinginan pihak tertentu untuk mengontrol perempuan melalui media?
Potret lain mengenai kekerasan terhadap perempuan juga terus muncul setiap hari dengan model, bintang film, dan selebritis yang difoto memakai rok sangat mini dan ketat, blus dengan belahan dada rendah. Mengapa bagian-bagian itu yang ditonjolkan oleh juru foto? Apakah bagian bagian tubuh perempuan yang tertutup itu lebih menggairahkan? Apakah itu merupakan nafsu-nafsu tersembunyi dari para pengambil gambar? Atau keinginan pihak tertentu untuk mengontrol perempuan melalui media? Anehnya, perempuan juga manerima adegan-adegan yang sebenarnya sangat merendahkan martabatnya itu.

Kalau bukan sebagai obyek seks atau obyek kekerasan, potret perempuan dalam media berubah secara ekstrim menjadi "perempuan yang melawan dominasi patriakh seperti pejuang di rimba Amazon", atau seperti perempuan sakti seperti "Mak Lampir" dalam sinetron yang kita saksikan setiap minggu.

Dalam arena politik pun juga terjadi kekerasan rerhadap perempuan. Jika politisi laki-laki menang dalam perebutan kursi pemilihan, media akan memotret para politisi tersebut berganding dengan istrinya masing-masing. Lalu diberitakan, kesuksesan politisi tersebut tidak lepas dari peran istrinya. Akhirnya, para istri tersebut sekadar pendukung suami, mereka bukan diri mereka sendiri.

Tetapi politisi perempuan yang berhasil dalam arena politik akan berdiri sendiri tanpa suami mereka. Media menghiraukannya, seakan-akan bukan hal yang pantas diliput. Kasus paling mutakhir ialah naiknya Arroyo sebagai presiden Phillipina menggantikan Estrada. Publik tidak banyak yang tahu siapa suami Arroyo, kecuali gambarnya yang sempat diliput pada saat memasuki Istana Malacanang.

Contoh lain adalah siapa yang tahu banyak tentang suami Margareth Thacher, mantan Perdana Menteri Inggris yang galak itu? Siapa yang tahu banyak tentang suami Benazir Butho, mantan Perdana Menteri Pakistan itu? Siapa pula yang tahu banyak tentang suami Megawati Soekarnoputri?

Tetapi siapa yang tidak tahu Hilary Clinton, sebagai istri Mantan Presiden Amerika Serikat, Bill Clinton? Siapa yang tidak tahu Ibu Tien Soeharto, sebagai istri mantan Presiden Soeharto? Siapa pula yang tidak tahu Barbara Bush, Nancy Reagan sebagai istri-istri mantan Presiden Amerika Serikat, Ronald Reagan dan 
George Bush? Dan siapa yang tidak kenal nama Sinta Nuriah Abdurrahman Wahid?

Mengapa ini terjadi? Karena ada mitos bahwa politik adalah dunia laki-laki. Perempuan politisi tidak perlu dimuat besarbesar, sebab mereka dianggap memasuki dunia yang bukan miliknya. Akibatnya, jumlah politisi perempuan dan perempuan yang berada di pusat-pusat pengambilan keputusan sangat sedikit. Sebagai gambaran, menurut survei Next Magazine, sebuah harian di Hong Kong, jumlah politisi perempuan adalah satu berbanding empat dengan laki-laki rekannya.Angka ini jauh lebih baik dibandingkan Korea yang hanya 6,2 \% atau satu terbanding 16. Sedangkan di Thailand $10 \%$ dan Indonesia $8 \%$.

\section{F. Penutup}

Uraian di atas menunjukkan bahwa ketidakadilan dan ketidak setaraan akibat jenis kelamin sosial (gender) baik melalui bahasa dengan pemilihan kata-kata yang kasar dan merendahkan martabat perempuan maupun melalui media yang terus menerus menayangkan perempuan sebagai obyek dan komoditas seks yang semuanya berarti kekerasan tampaknya masih akan terus berlangsung. Sebab, selain media memiliki otoritas sebagai pemegang pemberitaan sebuah peristiwa, perempuan sendiri sikapnya ikut membenarkan, menggarisbawahi dan menerima saja mitos dominasi laki-laki atas perempuan. Kalau masyarakat menilai perempuain tidak sepintar laki-laki, mereka cenderung menerima karena inereka menerima otoritas masyarakat.

Studi tentang perempuan tampaknya masih akan terbuka lebar dan menarik sebagai kajian multidisipliner untuk menelusuri ketidakadilan dan ketidaksetaraan yang berarti kekerasan dalam pandangan Galturig berdasarkan jenis perbedaan seks. Yang penting untuk dikaji lebih jauh ialah ketidakadilan di segala bidang: politik, ekonomi, sosial, dan bahasa. Lembaga Pusat Studi Gender barangkali akan bisa memulainya.
Kalau masyarakat menilai perempuan tidak sepintar lakilaki, mereka cenderung menerima karena mereka menerima otoritas masyarakat. 


\section{Daftar Pustaka}

Bourdie, Pierre. 1994. Language and Symbolic Power. Cambridge, Massachusetts:

Harvard University Press.

Foucault, Michel. 1972. The Archeology of Knowledge \& The Discourse on Language. New York : Pantheon Books.

Gadamer, Hans-Georg. 1977. Philosophical Hermeneutics. Barkeley Los Angeles, London: University of California Press.

Hartiningsih, Maria. 2000. "Menyoal Ideologi dalam Bahasa dan Gambar di Media Massa”, Kompas, 1 November..

Hikam, Muhammad A.S. 1996. "Bahasa dan Politik:Penghampiran "Discursive Practice", dalam Yudi Latif dan Idi Subandy (Eds), Bahasa dan Kekuasaan: Politik Wacana di Panggung Orde Baru. Bandung: Mizan.

Rahardjo, Mudjia. 2000. "Akar-Akar Penelitian Kualitatif, Teori, Jenis, dan Prosedurnya", Makalah, Disampaikan pada Workshop Penelitian Bahasa bagi Dosen Bahasa STAIN Malang, November-Desember 2000.

Sumaryono, E. 1993. Hermeneutik: Sebuah Metode Filsafat. Yogyakarta: Penerbit Kanisius.

Watts, Mark D., Domke, David., Shah, Dhavan V., Fan, David P.. 1999. Elite Cues and Media Bias in Presidential Campaigns: Explaining Public Perceptions of a Liberal Press. Comunication Research Journal, Vol. 26 No. 2, April 1999, New York: Sage Publications, Inc.

Windu, I Marsana. 2000. "Dimensi Kekerasan, Tinjauan Teoritis atas Fenomena Kekerasan, dalam Suseno, Franz Magnis (Pengantar) “Melawan Kekerasan Tanpa Kekerasan”. Yogyakarta: Pustaka Pelajar. 